\title{
Water allocations and mulching in castor bean crops in a semiarid Fluvic Neossol ${ }^{1}$
}

\author{
Dotações hídricas e cobertura morta na cultura da mamona em Neossolo Flúvico no \\ semiárido
}

\author{
Júlio José do Nascimento Silva2*, Abelardo Antônio Assunção Montenegro³, Elvira Maria Régis Pedrosa ${ }^{3}$, \\ Napoleão Esberard de Macedo Beltrão ${ }^{4}$ e Hugo Manoel Henrique ${ }^{5}$
}

\begin{abstract}
The influence of different irrigation levels, both with and without mulching, was evaluated for the growth variables of productivity, production components and water use efficiency, in a castor bean crop (Ricinus Comunnis) cv. BRS Energia, in a Fluvic Neossol of the semiarid in the Brazilian state of Pernambuco. The experimental design used was completely randomised in a factorial of 4 (irrigation levels) $\times 2$ (with and without mulch), with four replications. The irrigation levels were based on the evapotranspiration of the crop (ETc), with L1 $=60 \%$ ETc, $\mathrm{L} 2=80 \% \mathrm{ETc}, \mathrm{L} 3=100 \% \mathrm{ETc}$ and $\mathrm{L} 4=120 \% \mathrm{ETc}$. All growth variables showed significant differences to the mulch at 120 days after germination. The number of racemes per plant, percentage of bark, and water use efficiency responded significantly to the presence of mulch on the ground, while length of racemes, fruit yield and berry yield responded significantly to the isolated effects of the irrigation levels and ground cover. Levels L3 and L4 improved the performance of the crop, with an average productivity of over 2,360 $\mathrm{kg}$ berries ha-1.
\end{abstract}

Key words: Irrigation. Growth. Production components.

RESUMO - Avaliou-se a influência de diferentes lâminas de irrigação na presença e ausência de cobertura morta nas variáveis de crescimento, produtividade, componentes de produção e eficiência do uso da água, da cultura mamoneira (Ricinus Comunnis) cultivar BRS Energia em Neossolo Flúvico no semiárido pernambucano. O delineamento experimental utilizado foi o inteiramente casualizado em esquema fatorial 4 (lâminas de irrigação) $\times 2$ (com e sem cobertura morta) com quatro repetições. As lâminas de irrigação basearam-se na evapotranspiração de cultura (ETc), sendo L1 $=60 \% \mathrm{ETc} ; \mathrm{L} 2=80 \% \mathrm{ETc} ; \mathrm{L} 3=100 \% \mathrm{ETc}$ e L4 $=120 \%$ ETc. Todas as variáveis de crescimento apresentaram diferença significativa à cobertura morta aos 120 dias após a germinação. O número de racemos por planta, o percentual de casca e a eficiência no uso da água responderam significativamente à presença de cobertura morta no solo; enquanto o comprimento de racemos, a produtividade de frutos e produtividade de bagas responderam significativamente aos efeitos isolados das lâminas e da cobertura do solo. As lâminas L3 e L4 foram as que permitiram melhor desempenho da cultura, com produtividade média acima de $2.360 \mathrm{~kg} \mathrm{ha}^{-1}$ de bagas.

Palavras-chave: Irrigação. Crescimento. Componentes de produção.

\footnotetext{
*Autor para correspondência

Recebido para publicação em 06/06/2012; aprovado em 04/02/2014

Parte da Tese de Doutorado do primeiro autor; pesquisa financiada pelo CNPq, Finep e FACEPE

${ }^{2}$ Instituto Federal de Educação, Ciência e Tecnologia da Paraíba, Campus Princesa Isabel, AC Rodovia PB-426, s/n, Sitio Barro Vermelho, Princesa Isabel-PB, Brasil, juliojns1980@yahoo.com.br

${ }_{3}^{3}$ Departamento de Tecnologia Rural, Universidade Federal Rural de Pernambuco, Recife-PE, Brasil, abelardo.montenegro@yahoo.com.br, elvira.pedrosa@dtr.ufrpe.br

${ }^{4}$ Centro Nacional de Pesquisa do Algodão, EMBRAPA, napoleao.beltrao@gmail.com

${ }^{5}$ Universidade Federal Rural do Pernambuco, Recife-PE, Brasil, hugohmh@ hotmail.com
} 


\section{INTRODUCTION}

With intensification of the Brazilian National Biodiesel Program it is estimated that more than $50 \%$ of Brazil's energy comes from renewable sources (PEREIRA, 2007). Unlike the soybean, sunflower, groundnut and other oilseeds, the castor bean is not intended for human consumption, and consequently does not involve competition with that market (SILVA et al., 2009).

Barros Jr. et al. (2008) point out that as it is a plant with the capacity for satisfactory production even under conditions of low rainfall, the castor bean is an alternative crop of great importance in the Brazilian semi-arid region. Some authors have confirmed the importance of irrigation in increasing the productivity of the castor bean, with a beneficial effect on the number of racemes per plant and on seed weight (SILVA, 2008). The study of different irrigation levels is essential to determine the water requirements of a species, and the impact on growth and yield (SILVA et al., 2011).

Additionally, the use of ground cover on the soil together with irrigation can provide numerous benefits, such as better moisture retention, maintenance of a more stable temperature and conservation of the soil structure (MEDEIROS et al., 2007).

Non-destructive growth analysis is an important tool when evaluating the efficiency of an adopted management, and this is why it is widely used by researchers in the agricultural area with a view to studying the performance of crop systems (CARDOSO et al., 2006). For the castor bean, it is possible to highlight the studies of Ribeiro et al. (2012), who measured stem diameter, plant height and number of leaves; Aires, Silva e Eicholz (2011), who evaluated dry weight, leaf area, relative growth rate, net assimilation rate of the plants, seed to fruit ratio, grain yield per plant and productivity; and Barreto et al. (2010), who monitored plant height, stem diameter and number of leaves.

Given the above, the aim of this work was to evaluate the influence of different irrigation levels, both with and without mulching, on growth, productivity, yield components and water use and efficiency in castor-bean crops in a Fluvent Neosol on a familyfarming environment in the semi-arid region of the state of Pernambuco, Brazil.

\section{MATERIAL AND METHODS}

The study was conducted on an experimental plot on the Nossa Senhora do Rosário Farm, in Pesqueira, located in an alluvial valley in the Agreste region of the state of Pernambuco, $230 \mathrm{~km}$ from Recife and $613 \mathrm{~m}$ above sea level, at $8^{\circ} 34^{\prime} 17^{\prime \prime} \mathrm{S}$ and $37^{\circ} 1^{\prime} 20^{\prime \prime} \mathrm{W}$ (SOUZA; MONTENEGRO; MONTENEGRO, 2008).

Conventional tillage was carried out with disc harrow, followed by digging and fertilising in accordance with the soil analysis (Table 1) performed at the Laboratory of Soil Fertility of the Federal Rural University of Pernambuco (UFRPE). The amounts and fertilizers used were $2 \mathrm{t} \mathrm{ha}^{-1}$ of farmyard manure; $15 \mathrm{~kg} \mathrm{ha}^{-1}$ of nitrogen as foundation and $20 \mathrm{~kg} \mathrm{ha}^{-1}$ as cover, the source of which was Calcium Nitrate, as recommended by Cavalcanti et al. (2008).

Castor beans (Ricinus communis L), cv. BRSEnergia were used in the experiment, planted four seeds per hole, in an area of $500 \mathrm{~m}^{2}$ and at a spacing of $0.75 \mathrm{~m} \mathrm{x} 1 \mathrm{~m}$, making up a stand of 666 plants.

The physical attributes of the area under study, determined according to Empresa Brasileira de Pesquisa Agropecuária (1997), are described in Table 2, for the layers of 0 to 20 , and 20 to $40 \mathrm{~cm}$. The textural class is Sandy loam.

Figure 1 shows soil water-retention curves for the 0 to 20 and 20 to $40 \mathrm{~cm}$ layers respectively, in accordance with Empresa Brasileira de Pesquisa Agropecuária (1997).

The experiment lasted 120 days. A localised, selfcompensating drip irrigation system was used, with one emitter per plant, following the same spacing as the lines of crops, and having a nominal flow rate of $4 \mathrm{~L} \mathrm{~h}^{-1}$ and a working pressure in the 5 to $40 \mathrm{kPa}$ range, in accordance with the manufacturer.

The experimental design was completely randomised, in a $4 \times 2$ factorial design (irrigation $x$ with and without mulching) with 4 replications. Irrigation levels were based on crop evapotranspiration (ETc), where L1 $=60 \%$ ETc, L2 $=80 \%$ ETc, L3 $=100 \%$ ETc and L4 $=120 \%$ ETc. The mulch used was based on ground up Elephant Grass (Pennisetum purpureum) at a density of $12 \mathrm{tha}^{-1}$. There were a total of 32 experimental plots with a useable area of $2.25 \mathrm{~m}^{2}$ per plot.

Table 1 - Results of soil fertility analysis in the experimental area. Pesqueira, Pernambuco

\begin{tabular}{ccccccccccc}
\hline \multirow{2}{*}{ Sample } & $\mathrm{pH}$ & $\mathrm{P}$ & $\mathrm{Na}$ & $\mathrm{K}$ & $\mathrm{Ca}+\mathrm{Mg}$ & $\mathrm{Ca}$ & $\mathrm{Al}$ & $\mathrm{H}+\mathrm{Al}$ & $\mathrm{C} . \mathrm{O}$. & $\mathrm{M} . \mathrm{O}$. \\
\cline { 2 - 11 } & $($ water $-1: 2.5)$ & $\left(\mathrm{mg} \mathrm{dm}^{-3}\right)$ & & & $\left(\mathrm{cmol}_{\mathrm{c}} \mathrm{dm}^{-3}\right)$ & & & $\left(\mathrm{g} \mathrm{kg}^{-1}\right)$ \\
\hline N.S. Rosário & 6.02 & 100 & 0.14 & 0.25 & 4.5 & 2.8 & 0.0 & 3.31 & 0.24 & 0.42 \\
\hline
\end{tabular}


Table 2 - Analysis of texture, density (Ds), particle density (Dp) and total porosity (P) for soil of the experimental area. Pesqueira, Pernambuco

\begin{tabular}{|c|c|c|c|c|c|c|c|}
\hline \multirow{3}{*}{ Depth $(\mathrm{cm})$} & \multicolumn{6}{|c|}{ Attributes } & \multirow{3}{*}{ Textural Class } \\
\hline & Sand & Clay & Silt & Ds & $\mathrm{Dp}$ & $\mathrm{P}$ & \\
\hline & & $\mathrm{g} \mathrm{kg}^{-1}$ & & \multicolumn{2}{|c|}{$\mathrm{g} \mathrm{cm}^{-3}$} & $(\%)$ & \\
\hline $0-20$ & 647.9 & 154.4 & 197.8 & 1.44 & 2.61 & 44.86 & Sandy loam \\
\hline $20-40$ & 642.9 & 173.0 & 184.1 & 1.42 & 2.61 & 45.44 & Sandy loam \\
\hline
\end{tabular}

Figure 1 - Retention curves for the Fluvent Neosol. Pesqueira, Pernambuco

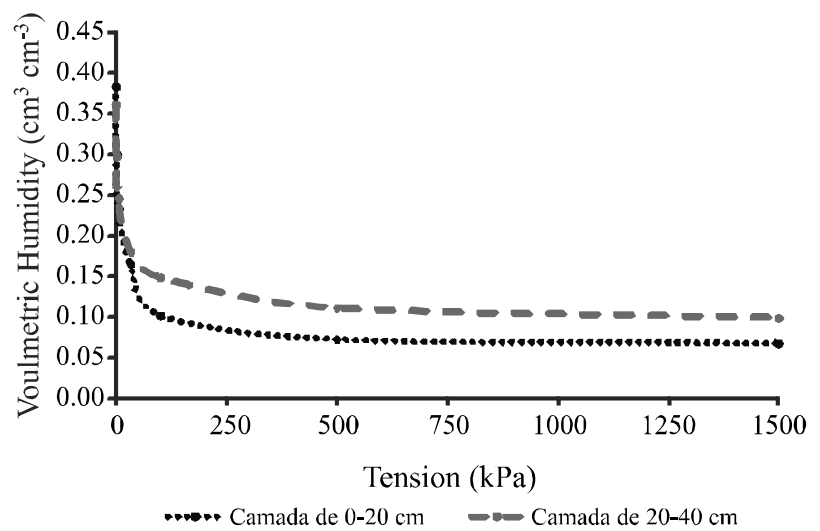

Evapotranspiration for the crop (ETc) was estimated using meteorological and crop data, as per Equation 1:

$$
E T c=\frac{E T o x K c x K l}{E a}
$$

where: $E T c=$ crop evapotranspiration $(\mathrm{mm}) ;$ ETo $=$ Reference evapotranspiration ( $\mathrm{mm}$ ), based on a Class "A" tank; Kc Crop coefficient, dimensionless, as a function of the phenological stage of the crop; $K l=$ locational coefficient, dimensionless (KELLER; BLIESNER, 1990); $E a=$ efficiency of the irrigation system.
The values used for the crop coefficients $(K c)$ were adapted from Dias (2009) and are described in Table 3. The tank coefficient, dimensionless, was estimated at 0.75 (ALLEN et al., 1998).

At phenological stage 3, there was a gradual increase in the crop coefficients (Kc's) of two-tenths (0.02) over the 18-day duration of this phase.

In order to carry out non-destructive analysis of the growth variables, eight measurements were taken at the following times: 15, 30, 45, 60, 75, 90, 105 and 120 days after germination (DAG), with three plants being evaluated per experimental lot. Non-destructive growth analyses were performed for stem diameter (SD), measured with calipers, plant height $(\mathrm{PH})$, measured with a ruler, and leaf area index (LAI). The determination of LAI was based on the methodology proposed by Severino et al. (2004), which is based on the length of the main and lateral inter-vein spaces of each leaf. Adding the results from all the leaves, the total leaf area for the plant is obtained, according to Equation 2.

$\mathrm{LA}=0,2439 \mathrm{x}(\mathrm{P}+\mathrm{T})^{2,0898}$

where: $L A=$ leaf area $\left(\mathrm{m}^{2}\right) ; P=$ length of the main vein; $T=$ average of the two lateral veins.

The LAI is then calculated as the ratio of LA to the crop area. For analysis of productivity, yield components and water use efficiency, a single harvest was carried out 120 days after germination (DAG), with three plants per experimental

Table 3 - Crop coefficients $(\mathrm{Kc})$ adopted for the castor bean crop in the experiment Pesqueira, Pernambuco

\begin{tabular}{lccc}
\hline Phenological stage & Phase characterisation & Duration in days & Kc \\
\hline F1 & From germination to 10\% ground cover & 14 & 0.75 \\
F2 & F1 - to inflorescence of 1st bunch & 34 & 0.85 \\
F3 & F2 - to inflorescence of 2nd bunch & 18 & $0.85-1.15$ \\
F4 & F3 - to maturation of 1st bunch & 36 & 1.15 \\
F5 & F4 - to maturation of 2nd bunch & 18 & 0.85 \\
\hline
\end{tabular}

Source: Adapted from Dias (2009) 
plot being sampled. Analyses were made of fruit yield (FP) $\left(\mathrm{kg} \mathrm{ha}^{-1}\right)$, berry yield (BP) $\left(\mathrm{kg} \mathrm{ha}^{-1}\right)$, number of racemes per plant (NRP), length of racemes (LR) $(\mathrm{cm})$; percentage bark (PB) and 100-seed weight (W100) (g). Finally the water use efficiency (WUE) $\left(\mathrm{kg} \mathrm{m}^{-3}\right)$ was analysed.

Variance analysis was used when investigating the variables of growth, productivity, yield components and water use efficiency; this due to the different irrigation levels and the presence and absence of mulching. To analyse the normality of the different factors, the KolmogorovSmirnov test was used. In all of these analyses the SAS software (SAS Institute, 1999) was employed.

Where significant, the data were subjected to regression analysis, using linear or quadratic models. Where there was no adjustment to the models, the averages were compared by Tukey test at $5 \%$ probability.

\section{RESULTS AND DISCUSSION}

Figure 2 shows the values of ETo, measured in a Class " $A$ " tank, together with the total rainfall for the crop cycle. Three events are seen to have occurred, at 31,32 and $33 \mathrm{DAG}$, totalling $154.5 \mathrm{~mm}$.

The results of the Kolmogorov-Smirnov test are shown in Table 4 and demonstrate a normal distribution of the data obtained.

Table 5 shows the effects of the irrigation treatments $(\mathrm{L} 1=496.17 \mathrm{~mm}, \mathrm{~L} 2=588.19 \mathrm{~mm}, \mathrm{~L} 3=679.77 \mathrm{~mm}$ and $\mathrm{L} 4=772.22 \mathrm{~mm}$ ) and ground cover (WM and NM) at 120 days after germination (DAG), as well as their respective interactions on the studied variables. Plant height $(\mathrm{PH})$, stem diameter (SD) and leaf area index (LAI) were not affected by the irrigation levels, being affected by mulching, at levels of 1.5 and $1 \%$ probability respectively. The lack of any significant interaction between factors (level $\times$ mulching) indicates that the effect from mulching on plant height is not dependent on the irrigation levels applied. The differences in growth produced by mulching can be seen in Table 6 .

Figures $3 \mathrm{~A}$ and $3 \mathrm{~B}$ show the behaviour of plant height $(\mathrm{PH})$ as a function of irrigation levels and the presence or absence of mulching respectively, during the crop cycle. For the effect from mulching, the WM treatment was better than

Figure 2 - Distribution of ETo and rainfall during the experiment, Pesqueira, Pernambuco

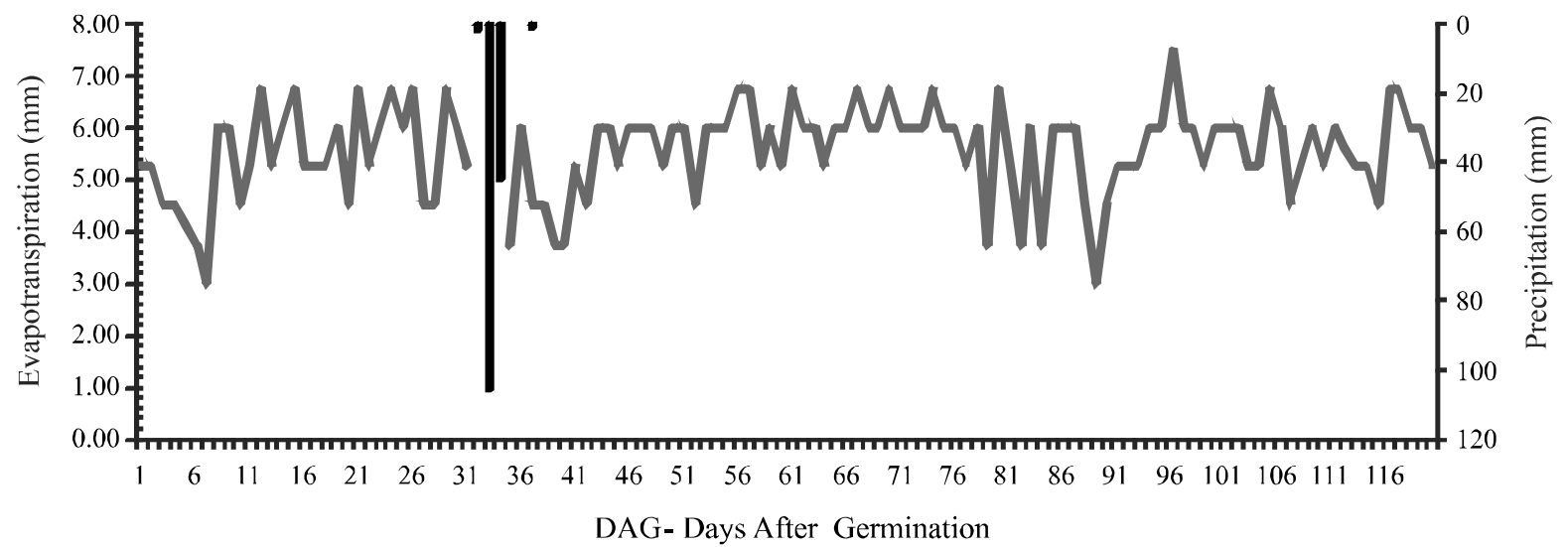

Rainfall

Eto Classe "A" Tank

Table 4 - Summary of the Kolmogorov-Smirnov test (KS) for variables obtained 120 days after germination: plant height (PH), stem diameter (SD), leaf area index (LAI), number of racemes per plant (NRP), length of racemes (LR), fruit yield (FP), berry yield (BP), percentage bark (PB), 100-seed weight (W100)

\begin{tabular}{lccccccccc}
\hline \multirow{2}{*}{$\mathrm{N}$} & PH & SD & LAI & NRP & LR & FP & BP & PB & W100 \\
\cline { 2 - 11 } & 32 & 32 & 32 & 32 & 32 & 32 & 32 & 32 & 32 \\
\hline K-S (D) & 0.09 & 0.09 & 0.13 & 0.13 & 0.14 & 0.11 & 0.07 & 0.09 & 0.19 \\
K-S $\alpha=0.05$ & 0.23 & 0.23 & 0.23 & 0.23 & 0.23 & 0.23 & 0.23 & 0.23 & 0.23 \\
\hline
\end{tabular}

$\mathrm{N}$ - Number of values 
$\mathrm{NM}$, with average respective values of 141.78 and $118.66 \mathrm{~cm}$. These values are higher than those found by Silva et al. (2009) in Barbalha, in the state of Ceará (maximum of $105.74 \mathrm{~cm}$ ). Whereas Dias (2009), also working in Barbalha and with the same cultivar, noted that plant height reached about 139.67 $\mathrm{cm}$, while recording an average height of $108.50 \mathrm{~cm}$, still less than that obtained in this study.

For all the growth variables under study, it can be seen that there was no effect from the absence of mulching until approximately $30 \mathrm{DAG}$; the absence of mulching having excelled from between 30 to 60 DAG. Such behaviour can be attributed to rainfall events during the study period promoting an increase in soil humidity until mid 75 DAG. From that time on, the treatment with mulching begins to surpass that with no mulching by allowing greater retention of soil moisture.

The reduction in crop growth in the absence of mulching can be attributed to a decrease in plant metabolism, and hence in growth, so as to prevent further loss of water to the environment (PEIXOTO et al., 2010).

Table 5 - Summary of variance analysis for growth variables at 120 days after germination in the castor bean, BRS Energia. Pesqueira, Pernambuco

\begin{tabular}{lccccc}
\hline \multicolumn{1}{c}{ SV } & DF & SS & MS & F & Pr $>$ F \\
\hline Irrigation level & \multicolumn{5}{c}{ Plant height } \\
Mulch & 3 & $1,416.45$ & 472.15 & 2.50 & 0.08 \\
Irrigation level $\times$ Mulch & 1 & $4,666.17$ & 4.666 .17 & 24.72 & $<0.0001$ \\
Residue & 3 & 229.52 & 76.51 & 0.41 & 0.75 \\
$\mathrm{CV}=10.44$ & 24 & $4,530.47$ & 188.77 & & \\
\hline
\end{tabular}

\begin{tabular}{lccccc}
\hline \multicolumn{5}{c}{ Stem diameter } \\
\hline Irrigation level & 3 & 24.66 & 8.22 & 0.76 & 0.53 \\
Mulch & 1 & 59.13 & 59.13 & 5.47 & 0.03 \\
Irrigation level $\times$ Mulch & 3 & 2.25 & 0.75 & 0.07 & 0.98 \\
Residue & 24 & 259.62 & 76.50 & & \\
$\mathrm{CV}=13.21$ & & & & \\
\hline
\end{tabular}

\begin{tabular}{lccccc}
\hline & Leaf area index & \\
\hline Irrigation level & 3 & 0.58 & 0.19 & 0.75 & 0.53 \\
Mulch & 1 & 3.15 & 3.15 & 12.36 & 0.002 \\
Irrigation level × Mulch & 3 & 0.24 & 0.24 & 0.31 & 0.82 \\
Residue & 24 & 6.12 & 0.26 & \\
CV=59.36 & & & \\
\hline SV - Sources of variation; DF - Degree of freedom; SS - Sum of squares; MS - Mean square; F- F value; Pr>F- Significance; CV - Coefficient of variation
\end{tabular}

SV - Sources of variation; DF - Degree of freedom; SS - Sum of squares; MS - Mean square; F - F value; Pr $>$ F - Significance; CV - Coefficient of variation

Table 6 - Average growth variables, with mulch (WM) and without mulch (NM), at 120 days after germination of the castor bean, BRS Energia. Pesqueira, Pernambuco

\begin{tabular}{lcccc}
\hline & Cover & PH & SD & LAI \\
\cline { 2 - 4 } & $\mathrm{cm}$ & $\mathrm{mm}$ & $1.16 \mathrm{a}$ \\
\hline $\mathrm{WM}$ & $143.69 \mathrm{a}$ & $26.25 \mathrm{a}$ & $0.54 \mathrm{~b}$ \\
\hline
\end{tabular}

Different letters in the same column indicate differences between averages at $5 \%$ probability by Tukey test. PH - plant height; SD - stem diameter; LAI - leaf área index 
Figures 3C and 3D show the behaviour of stem diameter (SD) during the study period. A gradual increase can be seen until the values for SD become stable at 105 DAG. Treatments with mulching are seen to be superior to those treatments with no mulching, with an average maximum value of $25.33 \mathrm{~mm}$ for the treatment with mulching and a minimum of $22.72 \mathrm{~mm}$ for that with no mulching, at $120 \mathrm{DAG}$.

It should be mentioned that these can be considered appropriate values. Silva et al. (2009) observed for SD, values in the order of $18.0 \mathrm{~mm}$, and Silva (2010) found an average value of $22 \mathrm{~mm}$ for SD. For the castor bean cv. Guarani, Bizinoto et al. (2010) found maximum and minimum values of SD in the order of 35 and $28 \mathrm{~mm}$ respectively, in Bom Jesus in the state of Goiás, higher than those obtained here. On the other hand, Carvalho et al. (2010) conducted an experiment in the municipality of Cariri in the state of Tocantins with the cultivars BRS Nordestina and BRS Paraguaçu, and found a maximum and minimum SD of 39.2 and $37.2 \mathrm{~mm}$ respectively.

Figure 3 - Evolution of the growth of the castor bean BRS Energia, for treatments of irrigation (L1, L2, L3, L4) and mulching (NM, WM). Pesqueira, Pernambuco
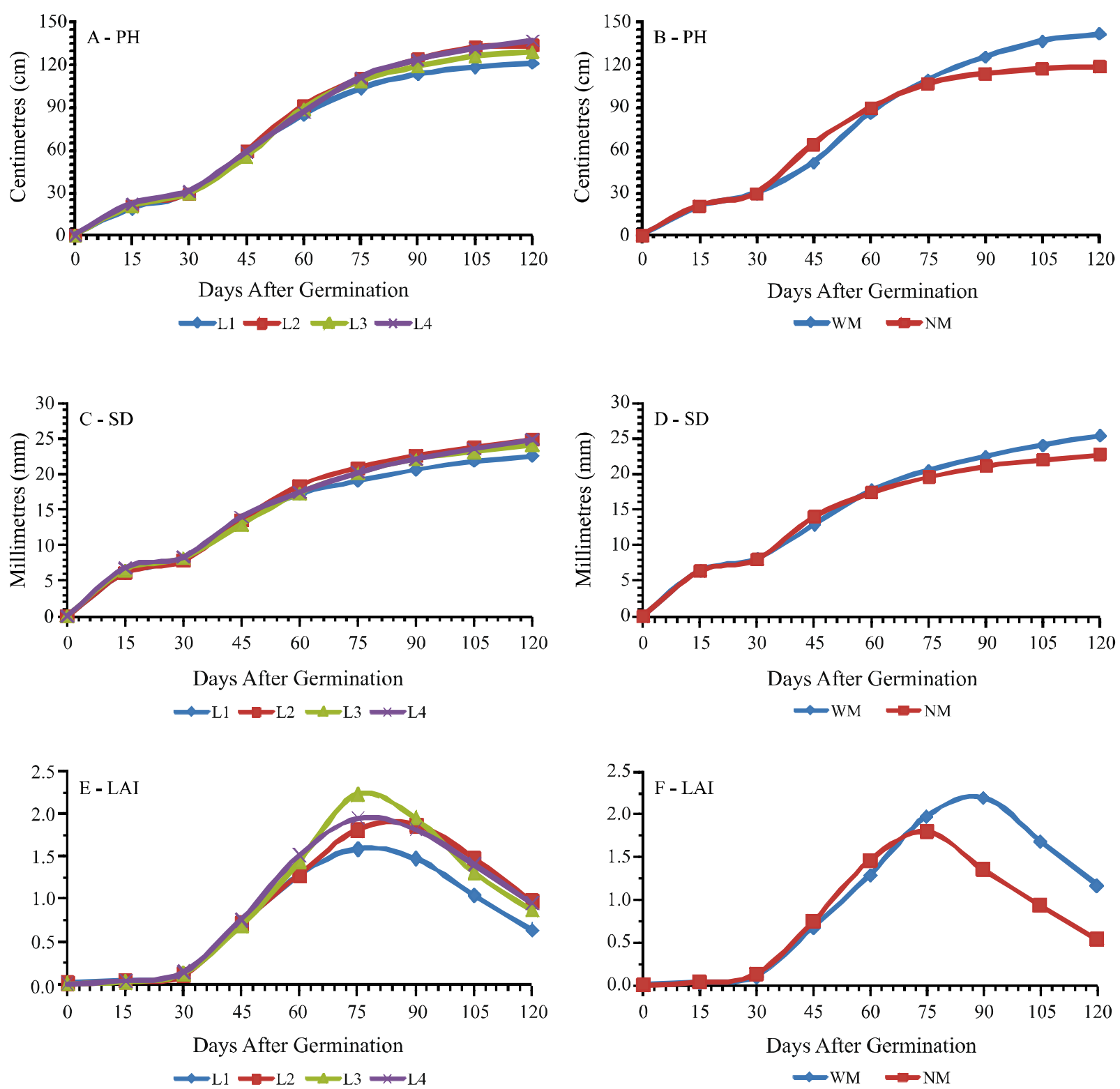

PH - plant height; SD - stem diameter; LAI - leaf área index 
Behaviour of the Leaf Area Index (LAI) is shown in Figures $3 \mathrm{E}$ and $3 \mathrm{~F}$. It can be seen that treatments with mulching were superior in relation to those with no mulching. In all treatments, there is a gradual increase, culminating in the greatest maximum LAI in the period between 75 and 90 DAG, and then decreasing until the end of the crop cycle. The treatment with the best performance was L3, with a maximum value of 2.22 at 75 DAG. The lowest LAI value was 0.63 for treatment L1at 120 DAG. The WM treatment produced a maximum LAI value of 2.18, significantly surpassing the NM treatment with 1.80. This result is associated with the lower availability of water in the soil causing a reduction in leaf area due to the drying out or fall of the leaves.

Peixoto et al. (2010), studying the performance of five castor bean cultivars (BRS 149 Nordestina, BRS 188 Paraguaçu, EBDA MPA 17, Mirante 10 and Sipeal 28), in the Reconcavo region of Bahia, obtained values of $2.12,1.68,1.36,1.06$ and 1.53 respectively for maximum LAI, all below the maximum obtained here.

Peixoto et al. (2010) also point out that high values for LAI are not always positively correlated with the final yield of the cultivated species. However, low values for this growth characteristic can limit the productive potential of the crops. Low LAI values limit yield, since LAI represents the storage system of the plant community and can be considered an important factor in productivity.

As for productivity, yield components and water use efficiency, Table 7 shows the effects of the irrigation and ground cover treatments at the end of the crop cycle (120 DAG), as well as their respective interactions on the variables under study at 1 and $5 \%$ levels of probability. It can be seen that all of the variables except W100 presented significant effects from the treatments used. Only W100 did not responded positively to the effect from the ground cover, while LR, FP and BP responded significantly to both the effect from irrigation levels (Table 8) and that from ground cover alone (Table 9), however with no significant difference for the interaction of these treatments on the variables.

Mulching made possible an increase of $22.8 \%$ in the number of racemes per plant, resulting in better crop performance. The results for NRP are superior to those obtained by Ferrari Neto et al. (2011) when working with the Hybrid Iris, in Botucatu, São Paulo, in different successive sowings intercropped with Pigeon pea (Cajanus cajan) and millet (Pennisetum glaucum), and obtaining around 2.2 racemes per plant.

There was a significant difference between irrigation levels in relation to the length of racemes (LR). Better performance was noted for L3, illustrated by $100 \%$
ETc, with an average value of $41.43 \mathrm{~cm}$. As for the effect from ground cover, a significant increase, of the order of $9.58 \%$, can be seen with mulch in relation to no mulch.

Bizinoto et al. (2010) evaluated LR in the castor bean cv. Guarani, influenced by different plant populations, in Bom Jesus, Goiás, and found no significant difference between treatments, obtaining maximum and minimum values of LR of 58 and $50 \mathrm{~cm}$ respectively. Silva et al. (2009), when studying the effects of irrigation levels on populations of castor bean plants cv. BRS Energia in Barbalha, Ceará, found maximum values for LR of $41 \mathrm{~cm}$. Dias (2009), also working with irrigation levels on the cultivar BRS Energia, obtained average maximum and minimum LR values of 41 and $33 \mathrm{~cm}$, similar to the results found here.

The variable fruit yield was also seen as statistically significant. It can be seen that the non-deficit irrigation levels produced a greater yield of berries, exceeding 3,300 kg ha-1. Furthermore, there was a significant effect from the mulch on the castor bean crop, since it resulted in an increase of the order of $31.09 \%$ in fruit productivity, improving crop performance compared to that seen in bare ground.

Silva et al. (2009) observed a fruit yield of $1,937.40 \mathrm{~kg} \mathrm{ha}^{-1}$ in the castor bean cv. BRS Energia. Additionally, Freitas et al. (2010) evaluated the performance of production variables in three castor bean cultivars (IAC Guarani, Mirante 10 and BRS Paraguaçu) under five levels of drip irrigation based on the evaporation of a Class "A" tank, at Pentecoste, Ceará, and noted than BRS Paraguaçu presented the greatest berry yield, of around $2,872.42 \mathrm{~kg} \mathrm{ha}^{-1}$, lower than the values obtained here.

However Moreira et al. (2009), in Fortaleza, Ceará, evaluated production factors in the IAC Guarani variety of castor bean under different levels of drip irrigation, also quantified from the evaporation measured in a Class " $A$ " tank, and found that irrigation based on an estimated $100 \%$ ECA provided the highest total fruit yield, of approximately $4,100 \mathrm{~kg} \mathrm{ha}^{-1}$, higher than the values found in this study.

There was a statistical significance for berry yield, where it was noted that the non-deficit irrigation levels gave the highest yields.

The significant effect from ground cover can also be seen, increasing the berry yield by about $27 \%$ compared to no cover, a substantial increase in crop yield. The values for productivity in the castor bean based on PB are much higher than the national average with reference to the 2010 harvest, which was approximately $621 \mathrm{~kg} \mathrm{ha}^{-1}$, according to Instituto Brasileiro de Geografia e Estatística (2011).

This result also exceeds that found by Silva (2010) who, when studying the effects of different effluents of treated domestic sewage and irrigation levels (100 and $120 \%$ 
Table 7 - Summary of variance analysis for productivity, yield components and water use efficiency in the castor bean, BRS Energy. Pesqueira

\begin{tabular}{|c|c|c|c|c|c|}
\hline SV & $\mathrm{DF}$ & SS & MS & $\mathrm{F}$ & $\operatorname{Pr}>\mathrm{F}$ \\
\hline \multicolumn{6}{|c|}{ Number of racemes per plant } \\
\hline Irrigation level & 3 & 0.27 & 0.09 & 0.86 & 0.48 \\
\hline Mulch & 1 & 0.73 & 0.73 & 6.99 & 0.01 \\
\hline Irrigation level $\times$ Mulch & 3 & 0.07 & 0.34 & 0.24 & 0.87 \\
\hline Residue & 24 & 2.50 & 0.10 & & \\
\hline $\mathrm{CV}$ & & 12.79 & & & \\
\hline \multicolumn{6}{|c|}{ Length of racemes } \\
\hline Irrigation level & 3 & 4.34 & 1.44 & 76.96 & $<0.0001$ \\
\hline Mulch & 1 & 0.74 & 0.74 & 39.63 & $<0.0001$ \\
\hline Irrigation level $\times$ Mulch & 3 & 0.10 & 0.03 & 1.70 & 0.19 \\
\hline Residue & 24 & 0.45 & 0.02 & & \\
\hline $\mathrm{CV}$ & & 2.27 & & & \\
\hline \multicolumn{6}{|c|}{ Fruit yield } \\
\hline Irrigation level & 3 & 875.97 & 291.99 & 5.48 & 0.0052 \\
\hline Mulch & 1 & 789.77 & 789.77 & 14.82 & 0.0008 \\
\hline Irrigation level $\times$ Mulch & 3 & 11.02 & 3.67 & 0.07 & 0.96 \\
\hline Residue & 24 & $1,278.76$ & 53.28 & & \\
\hline $\mathrm{CV}$ & & 13.81 & & & \\
\hline \multicolumn{6}{|c|}{ Berry yield } \\
\hline Irrigation level & 3 & 602.74 & 200.91 & 5.37 & 0.0057 \\
\hline Mulch & 1 & 421.48 & 421.48 & 11.26 & 0.0026 \\
\hline Irrigation level $\times$ Mulch & 3 & 6.77 & 2.26 & 0.06 & 0.98 \\
\hline Residue & 24 & 897.99 & 37.42 & & \\
\hline $\mathrm{CV}$ & & 13.51 & & & \\
\hline \multicolumn{6}{|l|}{ Percentage bark } \\
\hline Irrigation level & 3 & 0.49 & 0.16 & 1.87 & 0.16 \\
\hline Mulch & 1 & 1.07 & 1.07 & 12.15 & 0.002 \\
\hline Irrigation level $\times$ Mulch & 3 & 0.03 & 0.01 & 0.10 & 0.96 \\
\hline Residue & 24 & 2.11 & 0.09 & & \\
\hline $\mathrm{CV}$ & & 5.69 & & & \\
\hline \multicolumn{6}{|l|}{ 100-seed weight } \\
\hline Irrigation level & 3 & 0.22 & 0.07 & 2.19 & 0.12 \\
\hline Mulch & 1 & 0.04 & 0.04 & 1.13 & 0.30 \\
\hline Irrigation level $\times$ Mulch & 3 & 0.03 & 0.01 & 0.29 & 0.83 \\
\hline Residue & 24 & 0.81 & 0.03 & & \\
\hline $\mathrm{CV}$ & & 3.19 & & & \\
\hline \multicolumn{6}{|l|}{ Water use efficiency } \\
\hline Irrigation level & 3 & 0.01 & 0.003 & 1.25 & 0.31 \\
\hline Mulch & 1 & 0.02 & 0.02 & 11.29 & 0.003 \\
\hline Irrigation level $\times$ Mulch & 3 & 0.0002 & 0.0001 & 0.03 & 0.99 \\
\hline Residue & 24 & 0.053 & 0.002 & & \\
\hline $\mathrm{CV}$ & & 5.15 & & & \\
\hline
\end{tabular}

$\mathrm{CV}$ - Coefficient of variation 
Table 8 - Average values for productivity, yield components and water use efficiency for irrigation levels (L1, L2, L3 and L4) in the castor bean, BRS Energia. Pesqueira, Pernambuco

\begin{tabular}{lccccccc}
\hline Irrigation Level $(\mathrm{mm})$ & NRP & LR cm & FP kg ha $^{-1}$ & BP kg ha $^{-1}$ & PB \% & W100 g & WUE kg m \\
\hline L1 $=496.17$ & $5.17 \mathrm{a}$ & $29.96 \mathrm{c}$ & $2018.8 \mathrm{~b}$ & $1494.3 \mathrm{~b}$ & $26.18 \mathrm{a}$ & $31.13 \mathrm{a}$ & $0.30 \mathrm{a}$ \\
L2 $=588.19$ & $6.17 \mathrm{a}$ & $33.83 \mathrm{~d}$ & $2862.4 \mathrm{ab}$ & $2118.2 \mathrm{ab}$ & $25.82 \mathrm{a}$ & $32.52 \mathrm{a}$ & $0.36 \mathrm{a}$ \\
L3 $=679.77$ & $6.38 \mathrm{a}$ & $41.41 \mathrm{a}$ & $3318.3 \mathrm{a}$ & $2461.4 \mathrm{a}$ & $25.99 \mathrm{a}$ & $33.89 \mathrm{a}$ & $0.36 \mathrm{a}$ \\
L4 $=772.22$ & $6.21 \mathrm{a}$ & $38.68 \mathrm{~b}$ & $3337.2 \mathrm{a}$ & $2360.9 \mathrm{a}$ & $29.06 \mathrm{a}$ & $32.60 \mathrm{a}$ & $0.31 \mathrm{a}$ \\
\hline
\end{tabular}

Different letters in the same column indicate differences between averages at $5 \%$ probability by Tukey test

Table 9 - Average values for productivity, yield components and water use efficiency with mulch (WM) and no mulch (NM), in the castor bean, BRS Energy. Pesqueira, Pernambuco

\begin{tabular}{lccccccc}
\hline Ground Cover & NRP & LR cm & FP kg ha $^{-1}$ & BP kg ha $^{-1}$ & PB \% & W100 g & WUE kg m \\
\hline WM & $6.75 \mathrm{a}$ & $37.78 \mathrm{a}$ & $3415.0 \mathrm{a}$ & $2435.0 \mathrm{a}$ & $28.66 \mathrm{a}$ & $32.94 \mathrm{a}$ & $0.38 \mathrm{a}$ \\
NM & $5.21 \mathrm{~b}$ & $34.16 \mathrm{~b}$ & $2353.4 \mathrm{~b}$ & $1782.3 \mathrm{~b}$ & $24.87 \mathrm{~b}$ & $32.13 \mathrm{a}$ & $0.28 \mathrm{~b}$ \\
\hline
\end{tabular}

Different letters in the same column indicate differences between averages at $5 \%$ probability by Tukey test

ETc) on the growth of the castor bean BRS Energia in Ibimirim, Pernambuco, obtained a maximum production of $1,923.28 \mathrm{~kg} \mathrm{ha}^{-1}$. However, better results were found by Dias (2009) who, also working with this same cultivar in Barbalha, Ceará, at four irrigation levels, achieved a maximum productivity of the order of $3,361.72 \mathrm{~kg} \mathrm{ha}^{-1}$. Devide et al. (2010), in Pindamonhangaba, São Paulo, evaluated the performance of the castor bean IAC 80, cultivated under no-tillage in oat straw and intercropped with food crops, and obtained $1,060 \mathrm{~kg} \mathrm{ha}^{-1}$ of berries.

In this study, the percentage of bark (PB) did not differ for the irrigation levels adopted. For the treatments with and without mulch as ground cover, WM had a higher percentage of bark, of the order of $13.22 \%$, compared to no mulch. These results were better than those found by Zuchi et al. (2010), who evaluated the performance of the cultivars Al Guarany 2002, IAC 80, IAC 226 and BRS 188 Paraguaçu in Pelotas, Rio Grande do Sul, and obtained maximum values for $\mathrm{PB}$ of $39,44,34$ and $43 \%$ respectively.

The 100-seed weight (W100) also showed no difference for irrigation levels. Similar results were obtained by Soratto et al. (2011), Ferrari Neto et al. (2011), Diniz Neto et al. (2009) and Dias (2009), with maximum values for W100 of the order of 38.9, 40.3, 28.6 and $35.4 \mathrm{~g}$ respectively.

Dias (2009) points out that the WUE is the ability of the crop to assimilate carbon while limiting water loss through the stomata, and that this depends on the capacity for $\mathrm{CO}_{2}$ assimilation, photosynthetic efficiency and the type of plant.
In this work, the WUE showed a significant difference only for the presence of mulch, which consequently enabled better water use by the plant. With mulch, an increase of about $26 \%$ in WUE was observed when compared to no mulch. These values were improved by Dias (2009), who obtained 0.498 and $0.474 \mathrm{~kg} \mathrm{~m}^{-3}$, for the 2005 and 2006 crop years respectively.

\section{CONCLUSIONS}

1. W100 was the only variable that showed no significant difference between treatments. At 120 days after germination, all the growth variables responded significantly to mulching. NRP, PB and WUE responded significantly to mulch on the ground, while LR, FP and BP to the isolated effects of the irrigation levels and mulching;

2. Mulching resulted in better growth performance in the castor bean, Energy BRS compared to no mulching, and the non-deficit irrigation levels generated berry yields exceeding 2,360 $\mathrm{kg} \mathrm{ha}^{-1}$, considered high when compared to the national average.

\section{ACKNOWLEDGEMENT}

The authors wish to thank CNPq, PPGEAUFRPE, FACEPE and the CISA-UFPE-FINEP Project for their financial, logistical and institutional support. 


\section{REFERENCES}

ALLEN, R. G. et al. Crop evapotranspiration: Guidelines for computing crop water requirements. Rome: FAO, 1998. 300 p. (Irrigation and drainage paper, 56).

AIRES, R. F.; SILVA, S. D. A.; EICHOLZ, E. D. Análise de crescimento de mamona semeada em diferentes épocas. Ciência Rural, v. 41, n. 8, p. 1347-1353, 2011.

BARRETO, H.B.F.; et al. Avaliação do crescimento de acessos de mamona cultivada sob irrigação na região de Mossoró-RN, Brasil. Revista Verde, v. 5, n. 2, p. 185-193, 2010.

BARROS JÚNIOR, G. et al. Consumo de água e eficiência do uso para duas cultivares de mamona submetidas a estresse hídrico. Revista Brasileira de Engenharia Agrícola e Ambiental, v. 12, n. 4, p. 350-355, 2008.

BIZINOTO, T. K. M. C. et al. Cultivo da mamoneira influenciada por diferentes populações de plantas. Bragantia, v. 69, n. 2, p. 367370,2010

CARDOSO, G. D. et al. Uso da análise de crescimento não destrutiva como ferramenta para avaliação de cultivares. Revista de Biologia e Ciências da Terra, v. 6, n. 2, p. 79-84, 2006.

CARVALHO, E. V. et al. Densidade de plantio em duas cultivares de mamona no Sul do Tocantins. Revista Ciência Agronômica, v. 41, n. 3 , p. $387-392,2010$.

CAVALCANTI, F. J. de A. (Coord.). Recomendações de adubação para o Estado de Pernambuco: ( $2^{\mathrm{a}}$ aproximação). 2 ed. rev. Recife: IPA, 2008. 198 p.

DEVIDE, A. C. P. et al. Plantio direto de mamona 'IAC 80' com culturas alimentares. Ciência Agrotecnológica, v. 34, n. 3, p. 653659,2010 .

DIAS, J. M. Eficiência de uso da água e rentabilidade da cultura da mamona irrigada. 2009. 137 f. Tese (Doutorado em Recursos Naturais - Processos Ambientais) - Universidade Federal de Campina Grande, Campina Grande, 2009.

DINIZ NETO, M. A. et al. Adubação NPK e épocas de plantio para mamoneira. I - Componentes da produção e produtividade. Revista Ciência Agronômica, v. 40, n. 4, p. 578-587, 2009.

EMPRESA BRASILEIRA DE PESQUISA AGROPECUÁRIA . Manual de métodos de análises de solo. 2. ed. Rio de Janeiro: Ministério da Agricultura e do Abastecimento, 1997. 212 p.

FERRARI NETO, J. et al. Plantas de cobertura, manejo da palhada e produtividade da mamoneira no sistema plantio direto. Revista Ciência Agronômica, v. 42, n. 4, p. 978-985, 2011.

FREITAS, C. A. S. et al. Comportamento de cultivares de mamona em níveis de irrigação por gotejamento em Pentecoste, CE. Revista Brasileira de Engenharia Agrícola e Ambiental, v. 14, n. 10, p. 10591066, 2010.

INSTITUTO BRASILEIRO DE GEOGRAFIA E ESTATÍSTICA. Levantamento Sistemático da Produção Agrícola. Disponível em http://www.ibge.gov.br/home/estatistica/indicadores/agropecuaria/ 1spa/lspa_201111_6.sh. Acesso em: 28 dez. 2011.

KELLER, J.; BLIESNER, R. D. Sprinkler and trickle irrigation. New York: Van Nostrand Reinhold, 1990. 652 p.
MEDEIROS, J. F. et al. Produção de melão Cantaloupe influenciado por coberturas do solo, agrotêxtil e lâminas de irrigação. Horticultura Brasileira, v. 25, n. 4, p. 538-543, 2007.

MOREIRA, L. G. et al. Efeitos de diferentes lâminas de irrigação na produtividade da mamoneira variedade IAC Guarani. Revista Brasileira de Ciências Agrárias, v. 4, n. 4, p. 449-455, 2009.

NASCIMENTO, A. H. C. et al. Desenvolvimento da mamoneira com diferentes níveis de calagem em um Latossolo VermelhoAmarelo compactado. Revista Brasileira Ciências Agrárias, v. 5, n. 2, p. 163-169, 2010.

PEIXOTO, C. P. et al. Índices fisiológicos de cultivares de mamoneira nas condições agroecológicas do recôncavo baiano. Magistra, v. 22, n. 34, p. 168-177, 2010.

PEREIRA, F. S. G. Biomassa de oleaginosa como fonte alternativa de energia (Ricinus communis L.). 2007, 98 f. Dissertação (Mestrado Profissional em Tecnologia Ambiental) - Instituto de Tecnologia de Pernambuco, Recife, 2007.

RIBEIRO M. C. F. et al. Crescimento e produtividade da mamoneira irrigada com diferentes diluições de esgoto doméstico tratado. Revista Brasileira de Engenharia Agrícola e Ambiental, v. 16, n. 6, p. 639646, 2012.

SANTOS, J. F. et al. Componentes de produção e produtividade de mamoneira "BRS Energia" em função da adubação orgânica. Tecnologia \& Ciência Agropecuária, v. 4, n. 1, p. 01-07, 2010.

SAS INSTITUTE. The SAS System for windows: Release version: 6.8, 3. ed. Cary: 1998. 1 CD-ROM.

SEVERINO, L. S. et al. Método para determinação da área foliar da mamoneira. Revista Brasileira de Oleaginosas e Fibrosas, v. 8, n. 1, p. 753-762, 2004.

SILVA, A. R. A. et al. Desempenho de cultivares de girassol sob diferentes lâminas de irrigação no Vale do Curu, CE. Revista Ciência Agronômica, v. 42, n. 1, p. 57-64, 2011.

SILVA, M. M. Irrigação com efluentes secundários no crescimento, produtividade e concentração de nutrientes no solo e na mamoneira. 2010. 77 f. Tese (Doutorado em Engenharia Agrícola) - Universidade Federal de Campina Grande, Campina Grande, 2010.

SILVA, S. M. S. et al. Dotações hídricas em densidades de plantas na cultura da mamoneira cv. BRS Energia. Revista Brasileira de Ciências Agrárias, v. 4, n. 3, p. 338-348, 2009.

SILVA, S. M. S. et al. Desenvolvimento e produção de duas cultivares de mamoneira sob estresse salino. Revista Brasileira de Engenharia Agrícola e Ambiental, v. 12, n. 4, p. 335-342, 2008.

SOUZA, E. R.; MONTENEGRO, A. A. A.; MONTENEGRO, S. M. G. Variabilidade espacial da umidade do solo em lote irrigado no semiárido. Revista Brasileira de Recursos Hídricos, v. 13, n. 2, p. 23-28, 2008.

SORATTO, R. P. et al. Espaçamento e população de plantas de mamoneira de porte baixo para colheita mecanizada. Pesquisa Agropecuária Brasileira, v. 46, n. 3, p. 245-253, 2011.

ZUCHI, J. et al. Componentes do rendimento de mamona segundo a ordem floral e época de semeadura no Rio Grande do Sul. Revista Ciência Agronômica, v. 41, n. 3, p. 380-386, 2010. 